\title{
Transformation of public administration in digital conditions: world experience, prospects of Ukraine
}

\section{Svitlana Bondarenko A; Iryna Liganenko ${ }^{\text {B }}$; Viktoriya Mykytenko ${ }^{\mathrm{C}}$}

Received: April 10, 2020 | Revised: April 26, 2020 | Accepted: April 30, 2020

JEL Classification: O30, C18.

DOI: $10.33445 /$ sds.2020.10.2.9

\begin{abstract}
The purpose of the article is to highlight the main aspects of the transformation of public administration in the context of digitalization. It is established that digitalization is not a new model of public administration. It is proved that digital technologies as a tool for implementing the strategy of modernization of public administration, determine the main directions of change. It is proved that in the conditions of digital economy there is a transformation of the concept of public administration - in service. Digital transformation leads to a radical change in approaches to the organization of government with the use of digital technologies and algorithms. Digital technologies create opportunities for a completely different type of interaction between participants - in online communication. The basis for this nature of interaction is platform. To analyze the concept of digital transformation in public administration, the main stages of digitization are identified: digitization of processes, in which the introduction of traditional digital technologies to improve the efficiency of government, data management; e-government, which involves the introduction of digital technologies, especially based on the use of the Internet, to improve public administration; digital government, in which the latest generation of digital technologies (such as the Internet of Things, artificial intelligence, predictive analytics) allow to take into account the preferences of users in shaping the composition of services provided and the procedures associated with their receipt. A study of the main trends in the digitalization of the economy and public administration of Ukraine. Peculiarities of digitalization and transformation of public administration of the world are considered. Ukraine has developed "Concept for the development of the digital economy and society of Ukraine for 2018-2020" (Cabinet of Ministers of Ukraine, 2018). However, according to the results of the analysis, Ukraine has a low level of readiness for digitalization. In the UN ranking of e-government development in 2018, Ukraine ranked $82 \mathrm{nd}$. Ukraine is characterized by an insufficient level of infrastructural support for public administration transformation. Thus, the coverage of highquality Internet communication does not cover the entire territory of Ukraine and, as a result, reduces the rate of development of the digital economy. The analysis of the most successful countries of the world showed that the level of digitalization is directly dependent on the level of economic development of the country, infrastructure. The transformation of public administration in the context of digitalization will affect, first of all, the quality of public administration services, improving communication, reducing the cost of maintaining public administration, additional opportunities for businesses and citizens to receive services.
\end{abstract}

Key words: governance, digitization, transformation, digital economy.

\footnotetext{
A The National Defence University of Ukraine named after Ivan Cherniakhovskyi, Kyiv, Ukraine, Doctor of Economics, Leading Researcher at the Defence Management Education and Training Center, e-mail: lana.bond@ukr.net, ORCID: 0000-0002-1687-1172

${ }^{B}$ Prydunai Branch of Private joint-stock company «Higher educational institution «Interregional Academy of Personnel Management», Izmail, Ukraine, PhD in Economics, Associate Professor, Deputy Director for Educational and Methodical Work, e-mail: ir-vit-lig@ukr.net, ORCID: 0000-0003-0716-289x

'S State Institution «Institute economics of natural resources and sustainable development of the NAS of Ukraine», Kyiv, Ukraine, Doctor of Economics, professor, chief researcher, e-mail: vmikitenko@ukr.net
} 


\section{Introduction}

The systemic crisis currently facing Ukrainian society has affected, among other things, public administration issues. Along with the fact that there is a transformation of industrial society to post-industrial, information - there is an active transformation of the concept of public administration - in the service. Therefore, the information infrastructure acquires special significance, the economic policy of the state undergoes significant restructuring. The fourth industrial revolution, which is causing the digital transformation of all spheres of society, is an evolutionary stage in the transition to an intelligent, "smart economy" and digital society through the large-scale introduction of digital technologies. As a result, new economic relations are formed, opportunities for business, communication, management, well-being at the personal, regional and national levels are expanded. Digital transformation leads to a radical change in approaches to the organization of government with the use of digital technologies and algorithms. The widespread use of digital infrastructure (mobile devices, wireless networks, personal computers) facilitates their integration into the system of administrative services. This takes public administration to a new level of relations with citizens, business structures, between public administration bodies and other areas of communication. In recent years, highly

\section{Material and methods}

According to the concept of technological singularity (Vernor Vinge, 1993, Vision-21), there will come a time when technological progress will become so rapid and complex that it will be inaccessible to understanding. This process is associated with the development of information technology, biotechnology, nanotechnology and cognitive technology. The interaction of all these technologies will create superhuman intelligence, a kind of network consciousness. Given that society is changing towards information, the category of "digital economy" has emerged and research is being developed countries and countries with economies in transition have been rapidly increasing the share of the digital economy in all spheres of life, including public administration. The introduction of the digital economy was preceded by information, which prepared the information and telecommunications infrastructure, provided access to training in information technology and their implementation in all spheres of life (economics, trade, business, management, etc.). Digital technologies create opportunities for a completely different type of interaction between participants - in online communication. The basis for this nature of interaction is platform. Quarantine and self-isolation have become a favorable environment for the explosive growth of new areas of business, as well as areas of public administration services: platforms and services for video conferencing (example, Zoom), CRM-systems; educational platforms, e-commerce and e-government. Thus, the assumptions of the study are that the digitalization of public administration provides a higher level of quality, effectiveness and efficiency of public administration as a whole or its individual parameters. Research hypothesis: the transformation of public administration in the context of digitalization goes in the direction of improving the quality and efficiency and effectiveness of public administration.

conducted on the impact of digitalization on society from various aspects. In the latest economic theories, the "digital economy" began to be distinguished as a separate category in the 90 s of the 20th century. Fundamentals of the fourth industrial revolution as systemic changes due to technology and in certain technological areas (digitization / digitalization, robotics, artificial intelligence, biotechnology, 3Dprinting, etc.) are represented by international institutions: European Commission, OECD, UNIDO, WEF [1-5]. Digitization gives public administration the latest tools and new 
opportunities. The study (Lee-Geiller, Lee, 2019) examines the importance of e-government websites in the process of involving citizens as active agents in government. It has been proven that a holistic model of government websites promotes democratic e-government. However, research shows that the success and expected effects of digitalization are possible only if the economy, institutional and infrastructural component of society is ready to implement digital technologies. Analysis of the degree of readiness of the economies of the former Soviet republics to transform into a digital economy showed three levels of their readiness: average (EGDI from 0.25 to 0.5 ), high (EGDI from 0.5 to 0.75 ) and very high (EGDI > 0.75) (Chernyakov M.K., Chernyakova M.M., 2019). A number of studies confirm the relationship between the level of development of e-government and the quality and efficiency of public services in general and by function (Moreno-Enguix, Lorente Bayona, Gras-Gil, 2019). There is a continuous transformation of the digital government, there is a constant search for innovative digital solutions to improve the efficiency of social, economic, political and other types of governance. Understanding and anticipating such changes is important for policymakers, government officials, researchers, and anyone who prepares, adopts, implements, or evaluates digital government decisions (Nam
T., 2019). After all, digitalization is not a new model of public administration, but only gives the public administration system the latest tools that can, under appropriate conditions, significantly improve the quality and efficiency of all public administration bodies. Digital transformation involves the digitalization of the entire state. This process is based on the idea that the state is a platform with a full focus of digital services on mobile devices. However, the extent to which these latest tools will ensure the efficiency and effectiveness of public administration, in fact, depends on the training and security of personnel, infrastructure, institutional, legal. Therefore, it is necessary to find optimal solutions at the intersection of the digital economy, technological innovation, policy and cooperation for the competitive development of the country.

Problem definition. The purpose of the article is research transformation of public administration in the context of digitalization through the prism of world experience and possible directions and prospects for Ukraine. Within the framework of this research the following problematic issues are singled out: to determine the main directions of public administration transformation under the influence of digital technologies; assess the dependence of the effectiveness of public administration on the level of digitalization.

\section{Results and discussion}

The introduction of digital technologies in public administration is a trend for all countries. Experience shows that only the systematic use of innovative information technologies in decision-making processes, including the formation of comprehensive strategies and programs for public sector reform, is a prerequisite for improving the welfare of society. Digitization of processes makes organizational changes in the work of the government, the functioning of government, increases transparency and accountability. Digital transformation forms the basis of such changes, the essence of which is to restructure and transform communication channels - digital interaction.
To analyze the concept of digital transformation in public administration, it is advisable to identify the main stages of digitalization. Thus, OECD experts identify three main stages of digital transformation:

digitalization of processes, within which the introduction of traditional digital technologies to improve the efficiency of government, data management;

e-government, which involves the introduction of digital technologies, especially based on the use of the Internet, to improve public administration;

digital government, in which the latest generation of digital technologies (such as the Internet of Things, artificial intelligence, 
predictive analytics) allow taking into account the preferences of users in shaping the composition of services provided and the procedures associated with their receipt.

Digitization of public administration includes several modules of electronic interaction:

G2C - between the state and citizens (Government-to-Citizen);
G2B - between government and business (Government-to-Business);

G2G - between different branches of government (Government-to Government);

G2E - between the state and government officials (Government-to Employees).

The main beneficiaries of digitalization of public administration are presented in Figure 1.

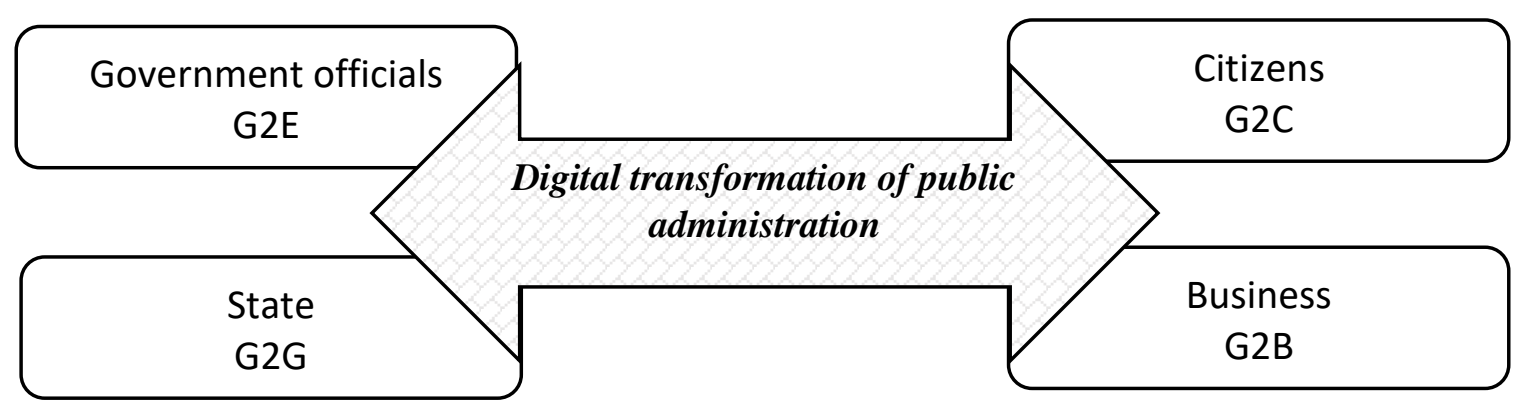

Fig. 1. The main beneficiaries of digitalization of public administration

According to experts, the digital transformation in public administration involves the stages of maturity from e-government to "smart government". These stages differ both in their priority aspects and in the channels and technologies of public services, as well as in the indicators of implementation, on the basis of which it would be possible to measure the implementation of a particular stage. It is important to emphasize that the technological solutions relevant to the initial stages of digital government maturity are not adequate for the later stages of its formation.

The first state program for the development of digital technologies - Digital Economy Agenda, was developed by the United States in 2015 (US, 2015). It includes four blocks that provide key opportunities to the country:

promotion of free and open internet;

ensuring trust and security in the network;

free access to the network and the opportunity to acquire professional skills by anyone;

promotion of innovations and breakthrough and subversive technologies of the new generation.

Thus, US policy is aimed at developing the digital economy, increasing the share of industries and industries involved in it, comprehensive support for entrepreneurs engaged in the IT industry. The influence of ICT in the field of public administration leads to rapid and significant transformations, increases the role of digitalization in the management process as a generating element of public value (Todorut, Tselentis, 2018).

At the European level, the "digital economy" category gained weight in 2010 during the European Commission's review of the Digital Single Market Strategy under the Europe 2020 strategy (European Commission, 2010).

In total, there are more than 30 national and regional national programs and strategies in the European Union aimed at accelerating the digital transformation of the economies of Europe and industry (Table 1).

In 2017, the EU Commission launched a single platform for information exchange - the EU Single digital market, which combines the national initiatives of the participating countries with a single course on digitalization.

This platform complements national digitization projects, initiates joint implementation of investment projects, provides them with financial support, serves as a forum for the exchange of experience, creates conditions for the training and retraining of highly qualified personnel. 
Table 1 - Strategies and programs of EU countries for digitalization of the economy

\begin{tabular}{|l|l|}
\hline \multicolumn{1}{|c|}{ Country } & \multicolumn{1}{c|}{ Strategy / Program } \\
\hline Austria & Industry 4.0 Austria \\
\hline Belgium & Made different - Factories of the future \\
\hline Czech Republic & Industry 4.0 \\
\hline Germany & Industry 4.0 \\
\hline Denmark & Manufacturing Academy of Denmark (MADE) \\
\hline Spain & Industry Connected 4.0 \\
\hline France & Alliance for the Future Industry \\
\hline Hungary & IPAR4.0 National Technology Initiative \\
\hline Italy & Industry 4.0 \\
\hline Lithuania & Praon 4.0 \\
\hline Luxembourg & Digital for Industry Luxembourg \\
\hline Netherlands & Smart Industry \\
\hline Poland & Initiative and Platform Industry 4.0 \\
\hline Portugal & Industry 4.0 \\
\hline Sweden & Smart Industry \\
\hline Great Britain & Digital Strategy 2017 \\
\hline
\end{tabular}

The platform combines all possible resources for the creation of digital technologies and digital industrial platforms, including highperformance cloud infrastructure for science and innovation, implements tests of large-scale projects, develops standards for their implementation.

The ranking of countries according to the EGovernment Development Index, according to 2018, is presented in Figure 2.

\section{Countries in the UN E-Government ranking in 2018}

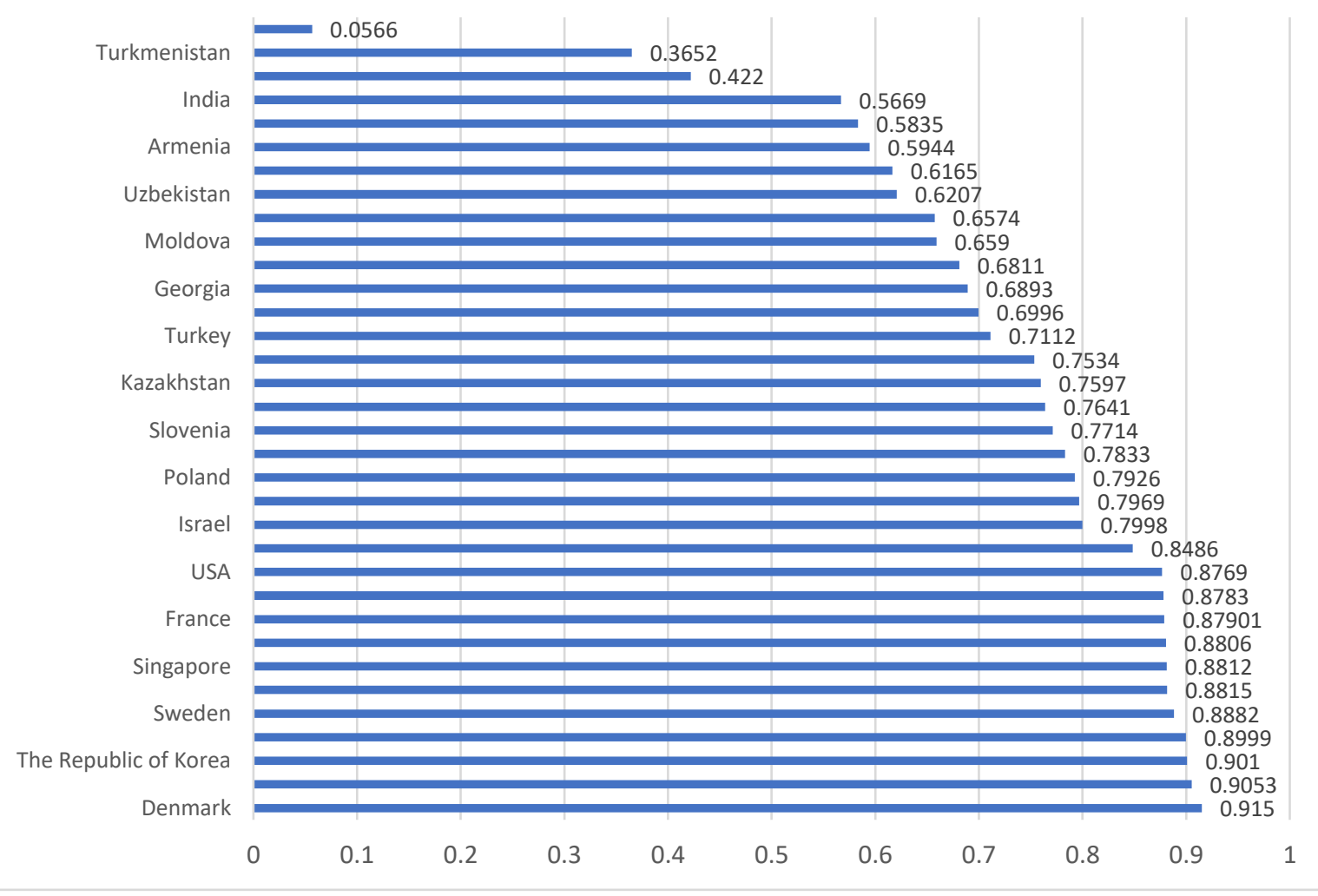

Fig 2. Countries in the UN E-Government ranking in 2018

The United Nations (UN) Global E- comprehensive indicator that assesses the Government Development Index is a readiness and capabilities of national governments to use information and 
communication technologies (ICTs) to provide public services to citizens. Produced every two years. The study contains data on the level of egovernment development in different countries, as well as a systematic assessment of trends in the use of ICT by government agencies. All countries covered by this study are ranked in the ranking based on a weighted index of assessments of three main components: the degree of coverage and quality of Internet services; level of ICT infrastructure development; human capital. In the UN ranking of e-government development in 2018, Ukraine ranked 82 nd (Fig. 3).

\section{Ukraine, E-Government rating in 2012-2018}

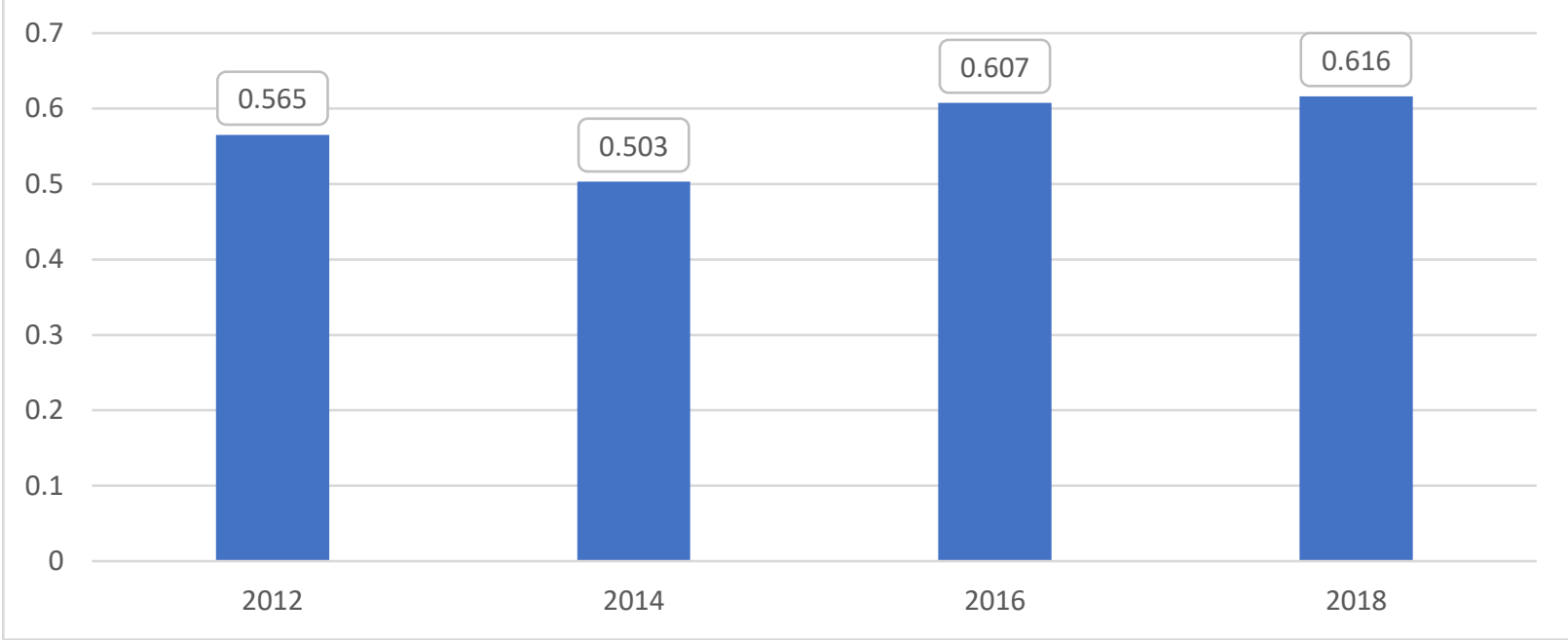

Fig. 3. Ukraine digital economy dynamics according to the UN E-Government rating

At the state level for the development of the digital economy of Ukraine developed conceptual principles of digitalization, which are reflected in the joint project "Digital Agenda of Ukraine 2020" (HITECH office, 2016). "Concept of development of the digital economy and society of Ukraine for 2018-2020" was also developed (Cabinet of Ministers of Ukraine, 2018). These documents define the following digitization goals:

digital modernization of all spheres of life and activity of the population;

transformation of the traditional economy into a competitive, efficient and investment-attractive one;

availability of digital technologies;

raising economic indicators at the international level;

opportunities for human resources development, innovative entrepreneurship, digital industry.

In 2019 approved Regulations on the Ministry of Digital Transformation of Ukraine. The Ministry of Digital Transformation of Ukraine (Ministry of Finance) is the central body of executive power that ensures the formation and implementation of state policy:

in the fields of digitalization, digital development, digital economy, digital innovations, e-government and e-democracy, information society development, informatization;

in the field of development of digital skills and digital rights of citizens;

in the areas of open data, development of national electronic information resources and interoperability, development of broadband Internet and telecommunications infrastructure, e-commerce and business;

in the field of electronic and administrative services;

in the areas of electronic trust services and electronic identification; in the development of the IT industry.

The purpose, principles and directions of digital modernization of the following branches of Ukraine are separately defined: education, medicine, transport infrastructure, tourism, public administration and environmental protection. 
The main parameters of digitalization of the from the state online. According to the economy (digitalization of the economy) of the parameters of digitalization of the economy, country are: Internet coverage; the share of e- Ukraine lags far behind the average level of the EU commerce in retail trade; the share of society that has digital competencies and receives services

(Fig. 4).

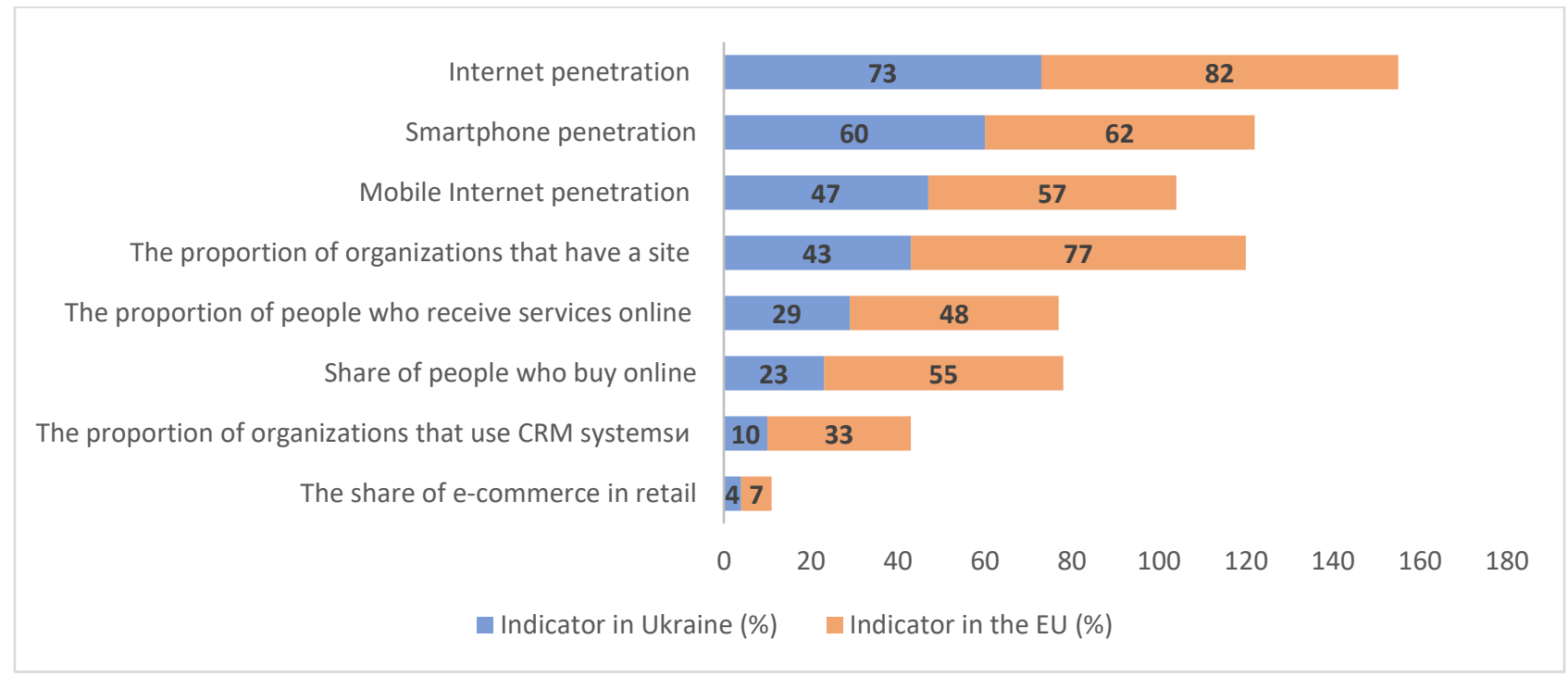

Fig. 4. Basic parameters of digitalization of the economy of Ukraine (digitalization of the economy)

The current state of Ukraine's digital indices is presented in Table 2. economy in terms of global development

Table 2 - Indicators of development of the digital economy of Ukraine

\begin{tabular}{|c|c|c|c|}
\hline Indicator & $\mathbf{2 0 1 6}$ & $\mathbf{2 0 1 7}$ & $\mathbf{2 0 1 8}$ \\
\hline Global Innovation Index (INSEAD, WIPO) & 56 & 50 & 43 \\
\hline ICT Development Index (ITU) & 78 & 79 & - \\
\hline Global Competitiveness Index (WEF) & 85 & 81 & 83 \\
\hline
\end{tabular}

Networked Readiness Index (WEF) - a network readiness index, an indicator of which characterizes the level of development of information and communication technologies (The Networked Readiness Index, 2016). The Global Innovation Index (INSEAD, WIPO) is a global innovation index published with the support of the World Intellectual Property Organization (The Global Innovation Index, 2018). According to this rating, Ukraine has rapidly improved its position in two years and has positive trends. ICT Development Index (ITU) - an index of information and communication technology development, which characterizes the achievements of countries in the development of information and communication technologies, is calculated and published by a special unit of the United Nations (International Telecommunications Union, 2017). Over the past two years, Ukraine's rating has not changed dramatically. Global Competitiveness Index (WEF) - an index of global economic competitiveness, calculated and published by the World Economic Forum (The Global Competitiveness Report, 20172018). Ukraine's rating on this index is unstable. The digital economy is directly connected to the Internet. According to the American 
company "We Are Social" and the Canadian in Ukraine is presented in Figure 5. company "Hootsuite", the state of digitalization

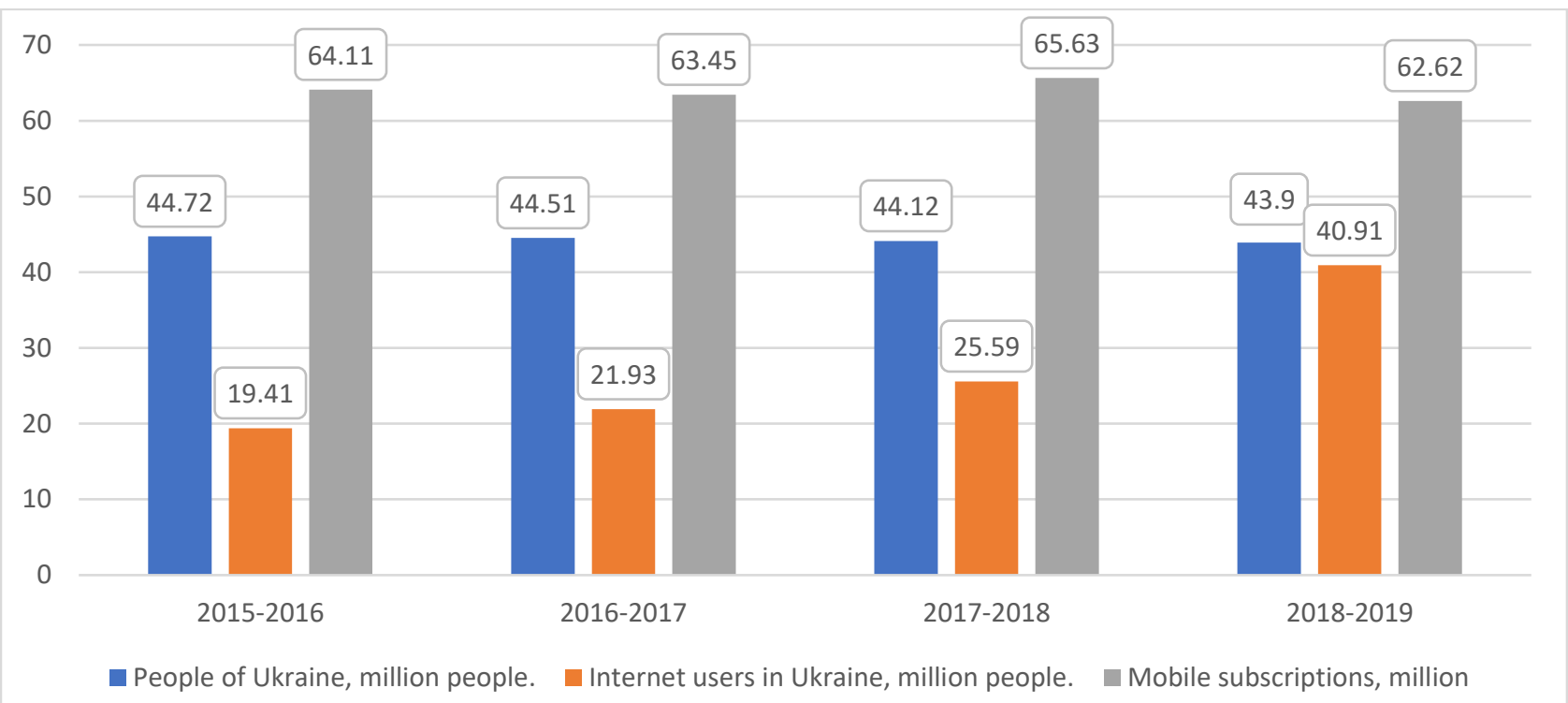

Fig. 5. Dynamics of Internet use in Ukraine in 2015-2019

As can be seen from Fig. 5, the number of Internet users in Ukraine has a positive trend. The analysis shows that the share of Internet users relative to the country's population is growing. Over the last four years, the number of mobile users in Ukraine has significantly exceeded the total population. This is due to the fact that a significant part of the population of Ukraine uses several mobile devices (smartphone, tablet). Types of Internet communication in Ukraine: cable communication, mobile Internet, Internet via radio, satellite Internet. There are more than 4,000 Internet providers in Ukraine. However, the quality and speed of Internet communication is necessary for stability in the development of the digital economy and the digital needs of society. Since 2015, Ukraine has launched a large-scale $3 G$ connection through the largest mobile operators (Kyivstar, VodafonUkraine and Lifecell). During the period of 2018, Ukraine significantly increased the opportunities for access to high-quality and high-speed Internet, in particular the introduction of mobile $4-G$ Internet connection. The results of a study by Cable.co.uk, a British provider that analyzes the availability of the Internet in 230 countries, show that mobile Internet in Ukraine is the cheapest in Europe and the fourth most accessible in the world. Thus, Ukraine creates sufficient conditions to ensure the availability of mobile Internet connection to every citizen. However, the coverage of high-quality Internet communication does not cover the entire territory of Ukraine and, as a result, reduces the speed of development of the digital economy.

Improving the quality of the mobile Internet is possible by upgrading infrastructure, investing in existing quality, and expanding communication channels. Networking needs to be optimized to improve your Internet connection. In Ukraine, the number of digital services is expanding, but it is not always and not everywhere possible to use them. In some small settlements there are no Internet communications. Thus, improving the Internet will increase the country's electronic capabilities, which will increase demand and competition in the digital economy.

To understand the level of readiness of the country for digitalization, the NRI network readiness index is used. The assessment of the current state of network readiness in the world according to the NRI (The Networked Readiness Index) is presented in table 3 (The Global, 2016). 
Table 3 - Group of countries-leaders in network readiness rating (NRI)

\begin{tabular}{|c|c|c|c|c|c|c|c|}
\hline Rating & Country & Rating & $\begin{array}{c}\text { Income } \\
\text { level } *\end{array}$ & Rating & Country & Rating & $\begin{array}{c}\text { Income } \\
\text { level }\end{array}$ \\
\hline 1 & Singapore & 6.0 & HI & 11 & Denmark & 5.6 & HI-OECD \\
\hline 2 & Finland & 6.0 & HI-OECD & 12 & Hong Kong & 5.6 & HI \\
\hline 3 & Sweden & 5.8 & HI-OECD & 13 & South Korea & 5.6 & HI-OECD \\
\hline 4 & Norway & 5.8 & HI-OECD & 14 & Canada & 5.6 & HI-OECD \\
\hline 5 & USA & 5.8 & HI-OECD & 15 & Germany & 5.6 & HI-OECD \\
\hline 6 & Netherlands & 5.8 & HI-OECD & 16 & Iceland & 5.5 & HI-OECD \\
\hline 7 & Switzerland & 5.8 & HI-OECD & 17 & New Zealand & 5.5 & HI-OECD \\
\hline 8 & Great Britain & 5.7 & HI-OECD & 18 & Australia & 5.5 & HI-OECD \\
\hline 9 & Luxembourg & 5.7 & HI-OECD & 19 & Taiwan, & 5.5 & HI \\
\hline 10 & Japan & 5.6 & HI-OECD & 20 & Austria & 5.4 & HI-OECD \\
\hline
\end{tabular}

* $\mathrm{HI}=$ high-income economy that is not a member of the OECD;

$H I-O E C D=$ high-income $O E C D$ members

The Digital Economy and Society Index (DESI) is a composite index that summarizes relevant indicators on Europes digital performance and tracks the evolution of EU member states in digital competitiveness.

Over the past year, all EU countries have improved their digital performance. Finland, Sweden, the Netherlands, and Denmark scored the highest ratings in DESI 2019 and are among the global leaders in digitization. These countries are followed by the United Kingdom, Luxembourg, Ireland, Estonia, and Belgium. Some other countries, however, still have a long way to go, and the EU as a whole needs improvement to be able to compete on the global stage (DESI, 2019) (Fig. 6).

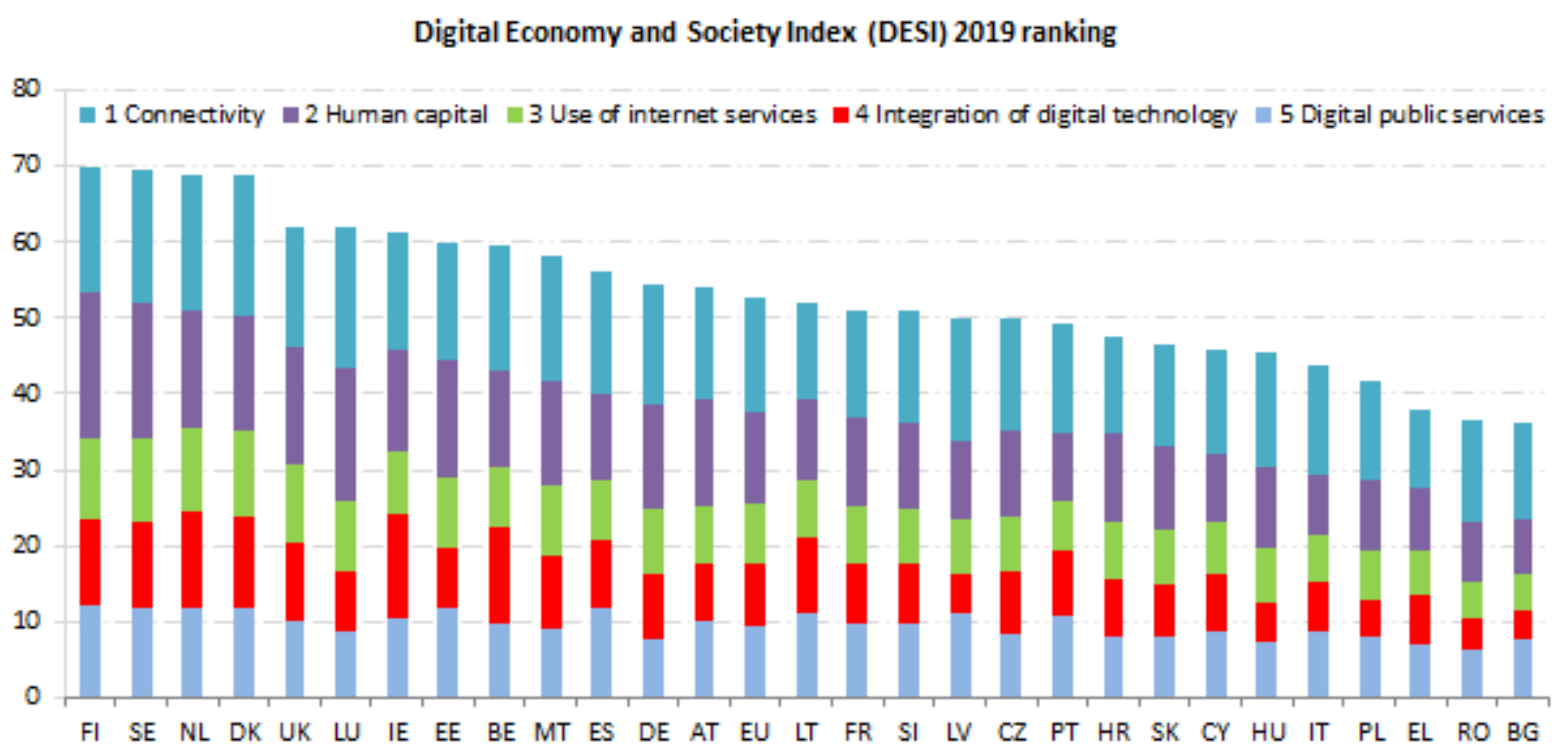

Fig 6. The Digital Economy and Society Index (DESI)

DESI 2019 (DESI, 2019)

The leaders in terms of network readiness are Singapore and European countries (Finland, Sweden, Norway, the Netherlands, Germany, Switzerland, Great Britain, Luxembourg), as well as the United States and Canada.

Digitization affected the system of tax and fee management, budget reporting, digital signature and identification of citizens, the transition to a single platform for e-government services, the system of electronic payments. The latter have significantly reduced the administrative burden on businesses and the public, making their 
interaction with government agencies faster, more efficient, more convenient and less expensive.

The proportion of people who use egovernment services (ie who visit or interact with government websites) has been growing steadily in recent years, but varies considerably from country to country. For example, in Denmark in 2016 it was $88 \%$, and in Brazil, Chile, Italy, Mexico and Colombia less than $25 \%$.

The number of citizens who submit completed forms online also varies widely: $50 \%$ or more in Northern Europe, Estonia, the Netherlands and France and less than $10 \%$ in Mexico and Japan. These differences are explained, in particular, by the underdeveloped infrastructure and limited supply of electronic services, as well as structural problems caused by institutional, cultural or economic factors (OECD, 2017).

According to the UN rating, according to the level of development of e-government EGDI, the top ten leaders in 2018 included Denmark, Australia, the Republic of Korea, Great Britain, Sweden, Finland, Singapore, New Zealand, France (UNE-Government, 2018).

Most countries have adopted strategies to digitize society and to implement them actively use breakthrough technologies: blockchain, big data, the Internet of Things, artificial intelligence and more. For example, in Denmark, the public services portal border.dk has been created, which contains a personalized page with services available to a particular citizen, a mandatory digital mailbox for individuals and businesses. There is also an open portal that provides access to personal health data (sundhed.dk). Effective communication with business is established through Virk.dki and Nem Handel resources - an open e-business environment that allows companies to securely and securely send standardized electronic invoices (UNEGovernment, 2018). Thanks to the Digital Strategy for 2016-2020, which will regulate the process of digitalization of the public sector, as well as determine the vector of its interaction with commercial organizations and industry, Denmark is successfully continuing to develop digital public administration and e-services. Among the priorities is the creation of a platform that will simplify business management and reduce its administrative burden through the introduction of automatic reporting. At the same time, companies will have access to more public sector data, which can be the basis for new business opportunities and innovations (The Digital strategy, 2016-2020).

The highest ratings for e-government informatization and development are in the Republic of Korea. The Smart eGovernment Plan, formulated in 2011, provided a wide range of public services based on mobile platforms. Portals have been created to provide customs, tax, civil, patent services to citizens of the country, as well as an online platform e-People for civil appeals to administrative institutions, an online system for managing government business procedures online-Onnara (Korea, 2020).

The e-Government Master Plan developed in the country until 2020 envisages the transformation of public administration on the basis of intelligent information technologies to create a new ecosystem that will become a platform for government innovations implemented for sustainable growth. Among the main tasks - the formation of new digital industries, led by the public sector, cloud administrative information security infrastructure of the new generation, strengthening its position as a major exporter of e-government (Korea, 2020).

One of the factors in the spread of digital public services in Estonia was the development of a digital ecosystem based on blockchain technology, which brought together participants from all spheres of statehood in a single information space. The formation of a digital society in Estonia has become possible thanks to the existing infrastructure, which is based on a decentralized system connected to a series of networks.

In the UK, public sector development stimulates and implements R\&D funded through public-private partnerships and a public procurement system that includes a platform for high-tech small businesses.

The analysis shows that the digitalization of public administration significantly increases the effectiveness of public sector interaction with society. Thus, Denmark's transition to the provision of public services only in digital format has reduced the cost of the service by $50 \%$. A 
large-scale digital and technology optimization program has allowed the UK to save up to $\$ 4.3$ billion in 2016.

Saudi Arabia uses big data for digital employment services, which reduces bureaucracy and saves up to $\$ 1$ billion. for a year.

The analysis of foreign experience shows that the formation of a strategy for the transition to a digital government focused on citizens - a basic condition for the fullest realization of the opportunities provided by the digital transformation of public administration and society as a whole. At the same time, it requires the introduction of new forms of interaction, skills, multifaceted use of large data sets.

Implementation of projects on digitalization of public administration, as a rule, is aimed at improving the effectiveness of public administration, including the quality of public services and / or its efficiency, ie to reduce the costs of the state, business and / or citizens related to the implementation of other government functions.

The values of the following indicators for each country were used as factors in assessing the level of digitalization of public administration:

e-government index calculated by the UN $\left(\mathrm{x}_{1}\right)$; e-participation index calculated by the UN $\left(x_{2}\right)$; indicator "share of citizens who use the Internet to send completed forms through government websites" $\left(x_{3}\right)$, which reflects the degree of digitalization in the provision of public services and is calculated by the OECD.

As factors for the assessment of public administration were used indicators of public administration, calculated by the World Bank:

government performance index $\left(\mathrm{x}_{4}\right)$;

publicity and accountability index $\left(x_{5}\right)$;

corruption control index $\left(\mathrm{x}_{6}\right)$;

public expenditure efficiency index calculated by the World Economic Forum $\left(\mathrm{x}_{7}\right)$;

Doing Business, calculated by the World

Bank $\left(\mathrm{x}_{8}\right)$.

Correlation analysis was conducted according to data from 69 countries, for which data are available for all indicators used.

The matrix of paired correlation coefficients is given in table. 4.

Table 4 - Matrix of paired correlation coefficients for estimating the dependence of public administration parameters on digitization

\begin{tabular}{|c|c|c|c|c|c|c|c|c|}
\hline & $\mathrm{X} 1$ & $\mathrm{X} 2$ & $\mathrm{X3}$ & $\mathrm{X} 4$ & $\mathrm{X} 5$ & $\mathrm{X} 6$ & $\mathrm{X7}$ & $\mathrm{X} 8$ \\
\hline $\mathrm{X} 1$ & 1 & & & & & & & \\
\hline $\mathrm{X} 2$ & 0.756 & 1 & & & & & & \\
\hline $\mathrm{X3}$ & 0.631 & 0.329 & 1 & & & & & \\
\hline $\mathrm{X} 4$ & $\mathbf{0 . 8 5 9}$ & 0.518 & 0.695 & 1 & & & & \\
\hline $\mathrm{X} 5$ & 0.543 & 0.480 & 0.543 & 0.688 & 1 & & & \\
\hline $\mathrm{X6}$ & $\mathbf{0 . 7 0 7}$ & 0.414 & 0.776 & 0.889 & 0.669 & 1 & & \\
\hline $\mathrm{X7}$ & 0.411 & 0.240 & 0.501 & 0.517 & 0.615 & 0.504 & 1 & \\
\hline $\mathrm{X8}$ & $\mathbf{0 . 7 0 9}$ & 0.504 & 0.507 & 0.785 & 0.413 & 0.636 & 0.337 & 1 \\
\hline
\end{tabular}

Correlation analysis revealed a strong positive relationship between the UN e-Development Index $\left(x_{1}\right)$ and a number of indicators that characterize the quality of public administration. Thus, the strongest correlation is observed between the level of e-government development and the government performance indicator $\left(x_{4}\right)$, where the correlation coefficient was 0,859 . There is also a strong correlation between the egovernment development index and the corruption control index $\left(\mathrm{x}_{6}\right)$. Thus, the analysis confirms the previously made assumptions about the positive impact of digital technologies, in particular the growth of non-cash payments, on reducing corruption. There is also a strong relationship between the e-government development index and the ease of doing business $\left(x_{8}\right)$. The value of the correlation coefficient of these indicators is 0.709 .

Analysis of foreign experience shows that in the framework of the implementation of digital government strategies are implemented tools aimed at increasing the efficiency of public administration, including:

the practice of calculating actual transaction costs (including to justify the transition to digital 
government);

technological assessment of business cases (which assumes that the results of the introduction of information technology transaction costs for the implementation of government functions for the implementation of which IT is implemented, should be reduced).

It should be noted that currently there are a number of legal, economic, technological, organizational and infrastructural limitations of digitalization of public administration, without removing (or significantly reducing) some areas of digitalization may be ineffective and / or ineffective. The key limitations of the transition to automated interaction are related to the uneven level of development of digital infrastructure, the risks of technological failures and the risks of disclosure of trade secrets. The key risks of implementing digital technologies are:

loss of control in critical areas of public administration;

unauthorized use of personal data;

the possibility of human rights violations in automated management decisions;

organizational risks, including the resistance of the authorities to the transition from departmental informatization to platform (supradepartmental) decisions (risk of loss of control, fear of openness of their data).

The ability and feasibility of using digital technologies related to the Internet of Things and machine-to-machine interaction, largely depend on the quality of mobile communications and its cost. Effective implementation of inter-machine interaction requires widespread penetration of fifth generation (5G) networks, which is unrealistic in the coming years for underdeveloped countries.

However, with the current level of development of information and computer technology infrastructure, it is possible to test the systems of inter-machine interaction on some examples, which minimize the other risks mentioned above (for example, in the formation of budget and tax reporting in the public sector). In the medium and long term, this practice can be implemented to automate the interaction of other organizations with government agencies.

The potential use of digital technologies can significantly reduce government intervention in economic and social processes, increase the efficiency and effectiveness of public administration. The effect of reducing the administrative costs of business, citizens and the state, increasing the availability of public (in a broad sense) services, the level of protection of citizens and minimizing the risk of harm in the controlled (supervised) areas can be significant. Mass implementation requires separate experiments and pilot projects (for example, on the automatic collection of statistics), as well as the elimination of infrastructural, legal and organizational constraints.

\section{Conclusions}

Thus, the digitalization of the economy has a significant impact on the ability to provide public administrative services. At the same time, digitalization itself is not a specific mechanism, but only a set of new tools and capabilities. The process of digital transformation of society has a significant impact not only on the available ways to solve the problems of public administration, but changes their composition and content characteristics, requiring a coordinated improvement of methodology and tools. Digital technologies are used for the purposes of planning, monitoring and evaluating the performance of public authorities. The effect of digitization is assessed by the impact of digital technologies on these results. Institutional conditions for public administration require expanding the range of applications of digital technologies at different stages and levels. Auger,

1) reduction of expenses for activity of state bodies - due to optimization of providing, invariant functions (back-offices of state bodies);

2) increasing the productivity of civil servants in the provision of public services and the implementation of control and supervision through standardization and modernization of administrative and managerial processes;

3 ) reducing the cost of creating and administering information resources and systems - through the reuse of information 
technology and services;

4) increasing the efficiency of budget expenditures for program (project) activities implemented by the authorities - by promoting and stimulating the introduction of digital technologies in the economy;

5 ) increasing the level of trust of citizens and businesses in government and officials, support for their decisions (policies) - through the formation of an ecosystem of public and private platforms.

Mechanisms of institutional support of digital transformation of public administration - the direction of further research.

\section{References}

1. For a European Industrial Renaissance. Communication from the Commission to the European Parliament, the Council, the European Economic and Social Committee and the Committee of the Regions. Brussels. 01/22/2014 52014DC0014. URL: https://eurlex.europa.eu/legal-content/EN /TXT/PDF/?uri=CELEX:52014DC0014\&from $=\mathrm{EN}$

2. Organization for Economic Cooperation and Development (OECD), "Enabling the Next Production Revolution: The Future of Manufacturing and Services - Interim Report" (Paris: OECD, June 2, 2016), URL: https://www.oecd.org/ mcm / documents / Enabling-the-next-production-revolutionthefuture-of-manufacturing-and-servicesinterimreport.pdf

3. United Nations Industrial Development Organization, 2017. Structural Change for Inclusive and Sustainable Industrial Development. Vienna. 180 p. URL: https://www.unido.org/sites/default/files/ files/2018-06/EBOOK_Structural_Change. pdf

4. United Nations Industrial Development Organization, 2017. Industrial Development Report 2018. Demand for Manufacturing: Driving Inclusive and Sustainable Industrial Development. Vienna. URL: https://www. unido.org/sites/default/files/files/ 2017-11 / IDR2018_FULL\% 20REPORT.pdf

5. Fourth Industrial Revolution on Supply Chains, 2017. World Economic Forum. URL:http://www3.weforum.org/docs/WEF$$
-
$$

Impact_of_the_Fourth_Industrial_Revoluti on_on_Supply_Chains_.pdf

6. The Digital Economy and Society Index (DESI).
URL:https://ec.europa.eu/digital-singlemarket/en/desi

7. European Commission

(2010), Communication from the European Commission to the European Parliament, the Council of the Economic and Social Committee and the Committee of the Regions, available at: eump.org/system/ Tsyfrovyj\%20poriadok\%20dennyj\%20dlia\% 20 Europe.pdf.

8. HITECH office (2016), Digital Agenda of Ukraine - 2020. Conceptual Background. Priority areas, initiatives, projects for digitization of Ukraine until 2020", available at: https://ucci.org.ua/uploads/files/58e7 8ee3c3922.pdf

9. Cabinet of Ministers of Ukraine (2018), Resolution "On approval of the Concept of development of the digital economy and society of Ukraine for 2018-2020 and approval of the plan of measures for its implementation", available at: https://zakon.rada.gov.ua/laws/show/672018-r/ed20180117\#n23

10. World Economic Forum (2016), "The Networked Readiness Index", available at: http://reports.weforum.org/globalinforma tion-technology-report-2016/networkedreadiness-index/?doing_wp_cron $=15583$ 49353.7612900733947753906250

11. The Global Innovation Index (2018), available at: https://www.globalinnovation index.org/gii-2018-report

12. International Telecommunications Union (2017), “ICT Development Index 20162017", available at: https://www.itu.int/ net4/ITU-D/idi/2017/index.html

13. The Networked Readiness Index [Electronic resource]. - Access mode: 
http://reports.weforum.org/globalinforma tion-technology-report-2016/networkedreadiness-index/?doing_wp_cron $=1558$ 349353.7612900733947753906250

14. The Global Information Technology Report 2016 - World Economic Forum. [Electronic resource] - Mode of access: http://www3.weforum.org/docs/GITR2016 /WEF_GITR_Full_Report.pdf

15. The Global Competitiveness Report 20172018. [Electronic resource]. - Access mode: http://www3.weforum.org/docs/GCR2017 2018/05FullReport/TheGlobalCompetitiven essReport2017-2018.pdf

16. OECD Digital Economy Outlook 2017: OECD (2017), OECD Publishing, Paris // https://espas.secure.europarl.europa.eu/o rbis/sites/default/files/generated/docume nt/en/9317011e.pdf

17. UNE-Government Survey 2018. Gearing EGovernment to support transformation towards sustainable and resilient societies //https://www.unescap.org/sites/default/f iles/E-Government\%20Survey\%202018_ FINAL.pdf.

18. A stronger and more secure digital Denmark. The Digital strategy 2016-2020. Denmark, May 2016 //https://digst.dk/media/16165/ ds_singlepage_uk_web.pdf

19. Korea e-Government Master Plan 2020 [Electronic resource]: National Information
Society Agency. https://www.nia.or.kr/ common/board/Download.do?bcldx=1905 $3 \& \mathrm{cbldx}=37989 \&$ fileNo $=1$

20. Chernyakov M. K., Chernyakova M. M. Forecasting the development trends of digital government (e-government) in postSoviet countries. Journal of New Economy. 2019. T. 20, № 4. S. 5-21. DOI: 10.29141 / 2073-1019-2019-20-4-1

21. Klaus Schwab. 2016. The Fourth Industrial Revolution: what it means, how to respond. URL: https://www.weforum.org/agenda/ 2016/01/the-fourth-industrial-revo lutionwhat-it-means-and-how-to-respond

22. Moreno Enguix M. del Rocio, Lorente Bayona L.V., Gras-Gil E. (2019). Can e-government serve as a tool for public authorities to manage public resources more efficiently?Journal of Global Information Management, vol. 27, no. 2, pp. 122-135. DOI: 10.4018 / JGIM.2019040107.

23. Nam T. (2019). Does e-government raise effectiveness and efficiency? Examining the cross-national effect. Journal of Global Information Management, vol. 27, no. 3, pp. 120-138. DOI: 10.4018/JGIM.2019070107.

24. Whitmore A. (2012). A statistical analysis of the construction of the United Nations EGovernment Development Index. Government Information Quarterly, vol. 29, no. 1 , pp. 68-75. 